\title{
Silica sol properties for construction
}

\author{
Larisa Svatovskaya ${ }^{1, *}$, Anastasia Sychova ${ }^{2}$, and Maxim Sychov ${ }^{3}$ \\ ${ }^{1}$ Emperor Alexander I Saint-Petersburg State Transport University (PGUPS), Moskovsky pr. 9, St. \\ Petersburg, 190031, Russia, \\ ${ }^{2}$ A.F. Mozhaysky Military-Space Academy, Zhdanovskaya st. 13, St.-Petersburg, 197190, Russia \\ ${ }^{3}$ Saint-Petersburg State Institute of Technology (Technical University), Moskovsky pr. 26, \\ St.Petersburg, 190031, Russia
}

\begin{abstract}
The article deals with a number of topical issues connected with transport construction and environmental pollution, such as heavy metal ion pollutions of soils, preservation of natural resources, technical properties of transport construction system, and building materials' improvement. The main aim of the study is to present new problem solutions and technologies for transport construction concerning pure substance use for lithosphere. Silica sol solution was chosen as this substance. The choice was made because of silica sol nature. Having important properties, it is the purest substance for the environment. Experimental methods were carried out. The study introduces new technologies of silica sol solution use in transport construction systems: silica sol detoxication technology (SDT) for soils, silica sol absorption technology (SAT), soil strengthening technology (SST), silica sol blocking action technology (SBT). The article shows the examples of these technologies' application and examines new main properties of construction systems.
\end{abstract}

\section{Introduction}

The paper presents new solutions of silica sol use in transport construction. 3 topical issues of transport construction systems are especially important for today's overconsumption of natural resources. They are $2,5 \%$ per capita consumption of natural resources instead of $1 \%$, lithosphere pollution by heavy metal ions and oil products during the construction of different structures, increase of building material durability to reduce the use of natural resources. It is known that more than $75 \%$ of lithosphere minerals are silicates and aluminosilicates, and the nature of these minerals makes them useful for lithosphere protection in transport construction. The main aim of the work is to show silica sol application in transport construction due to properties of the sol.

The papers [1-5] examine some properties of silica sol. The great positive argument is that silica sol is the purest substance for the environment. New opportunities of silica sol use technologies are of great interest now. The results of the work demonstrate the possibility of the study of silica sol useful properties to be applied in building systems and for environmental protection.

\footnotetext{
* Corresponding author: lbsvatovskaya@yandex.ru
} 
The main idea is to apply silica sol properties and the Table 1 illustrates silica sol technologies to be used in construction systems and working principles of silica sol properties.

Table 1. Silica sol properties and technologies for transport construction.

\begin{tabular}{|c|c|}
\hline The name of silica sol technology & $\begin{array}{l}\text { The principle of the technology based on the } \\
\text { properties of silica sol }\end{array}$ \\
\hline $\begin{array}{l}\text { 1.Silica sol detoxication technology for soils } \\
\text { (SDT) }\end{array}$ & $\begin{array}{l}\text { Reactions like (1) } \\
(1) \mathrm{Me}^{2+}+\mathrm{SiO}_{2} \cdot \mathrm{nH}_{2} \mathrm{O}+2 \mathrm{OH}^{-} \\
=\mathrm{MeO}^{-} \mathrm{SiO}_{2} \cdot \mathrm{nH}_{2} \mathrm{O}+\mathrm{H}_{2} \mathrm{O} \\
\Delta \mathrm{G}^{0}{ }_{298}<0\end{array}$ \\
\hline 2. Silica sol absorption technology (SAT) & $\begin{array}{l}\text { Improvement of a material surface properties due to } \\
\text { silica sol use }\end{array}$ \\
\hline 3. Soil strengthening technology (SST) & $\begin{array}{l}\text { Binding properties of silica gel through conversion: } \\
\mathrm{SiO}_{2} \cdot \mathrm{nH}_{2} \mathrm{O}(\mathrm{sol}) \rightarrow \mathrm{SiO}_{2} \cdot \mathrm{nH}_{2} \mathrm{O} \text { (gel) }\end{array}$ \\
\hline $\begin{array}{l}\text { 4. Silica sol blocking action technology } \\
\text { (SBT), or the "lithosafe" }\end{array}$ & $\begin{array}{l}\text { The use of an artificial stone as a safe for absorbed } \\
\text { pollutions from lithosphere and then their blocking } \\
\text { by silica sol screen }\end{array}$ \\
\hline
\end{tabular}

Thus, the Table 1 introduces 4 silica sol use technologies based on the properties of silica sol. Silica sol detoxication technology (SDT) is quite good for railway soil detoxication because railway soils are polluted by heavy metal ions. If there are heavy metal ions, $\mathrm{Cu}$ (II); $\mathrm{Pb}$ (II); Ni (II); Cd (II); Co (II), the reaction like (1) takes place (see the Table 1). Thermodynamic calculation determines $\Delta \mathrm{G}^{0}{ }_{298}<0$ for the reaction. Besides, another reaction can be performed for detoxication:

$$
\text { (2) } \begin{aligned}
\mathrm{Me}^{2+}+\mathrm{SiO}_{2} \cdot 2 \mathrm{H}_{2} \mathrm{O}+4 \mathrm{OH}^{-} & =\mathrm{MeO} \cdot \mathrm{SiO}_{2} \cdot 2 \mathrm{H}_{2} \mathrm{O} \downarrow+\mathrm{Me}(\mathrm{OH})_{2} \downarrow+\mathrm{H}_{2} \mathrm{O}, \\
\Delta \mathrm{G}^{0}{ }_{298}<0 &
\end{aligned}
$$

The results of the reactions (1) and (2) are heavy metal ion detoxication in soils provided that solubility product of $\mathrm{Me}(\mathrm{OH}) 2$ and $\mathrm{MeO} \mathrm{SiO} 22 \mathrm{H} 2 \mathrm{O}$ is less than $10-15$ and tolerable concentration (TC) of $\mathrm{Pb}$ (II) in a soil is $0,03 \mathrm{~g} / \mathrm{kg}$. The formation of substances with low solubility product is the base of SDT.

As an artificial stone has pores and capillaries it is possible to improve the surface of a stone when applying silica sol. The point of this technology is absorption of heavy metal ions by pores and capillaries of an artificial stone. That is why over such substances as $\mathrm{SiO} 2 \mathrm{n}$ $\mathrm{H} 2 \mathrm{O}$ the level of a stone hardness and geosphere protection will be increased. It is the principle that SAT operates.

SST suggests the idea of silica gel's binding properties application. For soil strengthening $\mathrm{Na} 2 \mathrm{SiO} 3$ is used and, as a result of $\mathrm{Na} 2 \mathrm{SiO} 3$ reaction with water, silica gel and $\mathrm{NaOH}$ form: $\mathrm{Na} 2 \mathrm{SiO} 3+2 \mathrm{H} 2 \mathrm{O}=2 \mathrm{NaOH}+\mathrm{SiO} 2 \cdot \mathrm{H} 2 \mathrm{O}$. But the use of silica sol solution prevents a soil from $\mathrm{NaOH}$ pollution. Therefore, nowadays it is the purest substance for lithosphere. So, there is undoubted benefit from SST.

SBT uses the hard sol screen formed according to SAT. But before the screen formation an artificial stone is used to absorb oil products or solutions of oil with heavy metal ions. Then the polluted stone is covered by silica sol. In this case pollutions are blocked in the stone, and the material can be applied for useful purposes. That is the essence of SBT.

\section{Methods}

The experimental methods were carried out to examine these 4 technologies. For SDT about $30 \%$ silica sol solution was applied. The soil contained heavy metal ions to $1000 \mathrm{TC}$ (tolerable concentration) was irrigated by silica sol solution for its watering and saturation. 
The size of sol particles was nearly $10 \mathrm{~nm}, \mathrm{pH}$ of the solution - 10. 1-3 days later the aqueous extract from the soil samples were tested using selective electrodes for heavy metal ion presence.

For SAT 1,5-3\% silica sol solution was used. After 28 days of hardening the foam concrete articles with density $400 ; 500 ; 600 \mathrm{~kg} / \mathrm{m} 3$ were saturated with sol solution to improve the state of the surface and other technical properties. The test was done according to the Russian state standards.

For SST 30\% silica sol solution was applied to saturate the soil. Because of sol $\rightarrow$ gel conversion the soil was strengthened by silica gel. The method suggests $\mathrm{SiO} 2 \cdot \mathrm{nH} 2 \mathrm{O}$ use instead of $\mathrm{Na} 2 \mathrm{SiO} 3$ for strengthening, but without $\mathrm{Na}$ (I) pollution, as mentioned above.

During SBT the articles saturated with oil products or oil with heavy metal ion solutions were covered by silica sol to stop pollution extraction from a stone. The aqueous extract from the samples was tested by means of selected electrodes and the oil product analyzer. It should be noted that after treatment by silica sol solution an artificial stone acts like a safe, therefore, the polluted stone can be named the "lithosafe".

\section{Results and discussion}

The solution of silica sol with the size of particles up to $10 \mathrm{~nm}$ and $\mathrm{pH}=10$ was applied. For the model experiment of SDT the sandy soil polluted by heavy metal ions to $1000 \mathrm{TC}$ was used. The first technique was the analysis of the aqueous extract from the polluted soil that was mixed with silica sol. After mixing one could see sediments of different colours. The sediments of the reactions were investigated applying derivatographic method after their drying in the room at a temperature $\approx 20-25^{\circ} \mathrm{C}$. The Table 2 indicates the results of the sediment examination.

Table 2. Water loss in the sediments.

\begin{tabular}{|c|c|c|c|c|}
\hline $\begin{array}{c}\text { Sediments of the reactions between silica } \\
\text { sol and heavy metal ions in the model } \\
\text { aqueous extract of the polluted soil }\end{array}$ & $\begin{array}{c}\text { Mol mass of } \\
\text { ions, } g\end{array}$ & Water loss, $\%$ & $\begin{array}{c}\text { Colour of the } \\
\text { sediment }\end{array}$ \\
\cline { 1 - 2 } silica sol & ions & - & 11,74 & white \\
\hline $\mathrm{SiO}_{2} \cdot \mathrm{nH}_{2} \mathrm{O}$ & - & 40 & 25,02 & white \\
\hline $\mathrm{SiO}_{2} \cdot \mathrm{nH}_{2} \mathrm{O}$ & $\mathrm{Ca}(\mathrm{II})$ & 63,5 & 9,0 & turquoise \\
\hline $\mathrm{SiO}_{2} \cdot \mathrm{nH}_{2} \mathrm{O}$ & $\mathrm{Cu}(\mathrm{II})$ & 59 & 7,78 & blue \\
\hline $\mathrm{SiO}_{2} \cdot \mathrm{nH}_{2} \mathrm{O}$ & $\mathrm{Co}(\mathrm{II})$ & 58,7 & 12,5 & green \\
\hline $\mathrm{SiO}_{2} \cdot \mathrm{nH}_{2} \mathrm{O}$ & $\mathrm{Ni}(\mathrm{II})$ & 207,2 & 9,89 & white \\
\hline $\mathrm{SiO}_{2} \cdot \mathrm{nH}_{2} \mathrm{O}$ & $\mathrm{Pb}(\mathrm{II})$ & & & \\
\hline
\end{tabular}

The analysis of Table 2 shows that:

1) water loss is different in various sediments;

2) light ion of $\mathrm{Ca}$ (II) (for comparison) increases the water loss. It makes possible to assume that the formation of calcium silicate hydrates takes place;

3) heavy metal ions decrease water loss. It makes possible to assume that the formation of heavy metal ions' silicates occurs.

The second technique was to mix the sandy soil with heavy metal ion pollution and after its saturation with silica sol for 3 days the aqueous extract of the sandy soil was tested for heavy metal ion presence. They were not found. Thus, thermodynamic and experimental values coincided. The practical experiment was done with the areas of different sizes $\approx 10 \mathrm{~m} 2$ and $20 \mathrm{~m} 2$ in operation, the soil in the experiment had particles $\approx 3-5 \mathrm{~nm}$ in diameter. The sediments of the reactions between silica sol and heavy metal ions in the model aqueous extract of the polluted soil were obtained. The detoxication took place at the start of the interaction between the sandy soil and $30 \%$ silica sol solution. In 3 days the aqueous extract 
of the soil was taken. Selected electrodes did not show the presence of $\mathrm{Pb}$ (II) in it. So, it is possible to detoxicate a soil with more than $1000 \mathrm{TC}$ using silica sol solution.

The silica sol absorption technology (SAT) is new and quite effective. It is based on sol absorption through pores and capillaries. For SAT the foam concrete articles were used after process of hardening. After 28 days of hardening the foam concrete articles were saturated with silica sol during 1 day. The experiment has demonstrated the increase of the articles' properties. The Table 3 contains calculations of material consumption for the foam concrete articles during the experiment.

Table 3. The material consumption for foam concrete.

\begin{tabular}{|c|c|c|c|c|c|c|c|c|}
\hline & \multicolumn{6}{|c|}{ Material consumption, per/m $\mathrm{m}^{3}$} & \multirow{2}{*}{ Flowability } \\
\cline { 2 - 7 } Density & Cement & Sand & Water & Additive & $\begin{array}{c}\text { Volume } \\
\text { of foam }\end{array}$ & $\begin{array}{c}\text { Water } \\
\text { in } \\
\text { foam }\end{array}$ & $\begin{array}{c}\text { Water } \\
\text { cement }\end{array}$ & $\begin{array}{c}\text { of mix, } \\
\text { cm. }\end{array}$ \\
\hline 400 & 160 & 160 & 67 & 2,64 & 820 & 68 & 0,84 & 32 \\
\hline 500 & 210 & 210 & 86 & 2,49 & 763 & 62 & 0,7 & 28 \\
\hline 600 & 260 & 259 & 104 & 2,33 & 712 & 58 & 0,62 & 24 \\
\hline
\end{tabular}

With the surfaces of the foam concrete articles having been watered by $3 \%$ silica sol solution, the Table 4 illustrates the properties of foam concrete of different density after the treatment by silica sol.

Table 4. The improvement of foam concrete properties using sol absorption technology (SAT).

\begin{tabular}{|c|c|c|c|c|}
\hline \multirow{2}{*}{$\begin{array}{c}\text { Density of foam } \\
\text { concrete, } \mathrm{kg} / \mathrm{m}^{3}\end{array}$} & \multicolumn{4}{|c|}{ Change of foam concrete properties, \%; after 28 days* } \\
\cline { 2 - 5 } & $\begin{array}{c}\text { Compressive } \\
\text { strength, }+\Delta \%\end{array}$ & Hardness, $+\Delta \%$ & $\begin{array}{c}\text { Frost resistance, } \\
\text { cycles, }+\Delta \%\end{array}$ & $\begin{array}{c}\text { Water } \\
\text { absorption, } \\
-\Delta \%\end{array}$ \\
\hline 400 & $10-15$ & 30 & $10-25$ & 65 \\
\hline 500 & $10-15$ & 40 & $10-25$ & 60 \\
\hline 600 & $15-20$ & 50 & $10-25$ & 60 \\
\hline
\end{tabular}

*the test was done according to the Russian state standards, $100 \%$ - for the foam concrete check specimens in 28 days.

Moreover, it should be noted that when applying SAT the surface of the foam concrete articles did not have salt efflorescence, i.e. it was pure because of $\mathrm{SiO} 2 \mathrm{H} 2 \mathrm{O}$ action. So, the problem of salt efflorescence on concrete surface can be solved, SAT being one of the solutions of this problem.

With reference to the Table 4 SAT can be named technology of preservation of natural substances in terms of cement technology. Taking into consideration the consumption of natural products, fuel and energy for $1 \mathrm{~m} 3$ of concrete manufacture, the calculations demonstrate the decrease of natural product consumption. Therefore, the application of SAT is the best for motorways' construction. There are some problems of concrete surface in construction, especially in transport construction, e.g. motorways and railways in operation. The paper examines 2 surfaces of B20, B30 concrete used in motorways' construction. They are outside and inside surfaces. Being under loads, outside surface must have enough hardness, strength (compressive and bending), frost resistance and pollution resistance. Inside surface must have protection at least against water absorption. Road articles' treatment by silica sol was applied using 3\% silica sol solution for saturation. The details of the technology, the class of concrete, its properties and examples of the use were examined. The research has shown new possibilities of the quality improvement using the new technology (SAT), particularly, pores and capillaries' healing by means of cement sol on the concrete surface that resulted in concrete hardness increase and water absorption decrease. 
Soil strengthening technology (SST) is the result of sol $\rightarrow$ gel conversion. The technology is nearly the same as SDT but, unlike this, during SST the process does not take place immediately because it takes more time for sol $\rightarrow$ gel conversion and for gel hardening. As the practical experiment has shown, it took a few days for strengthening because $\mathrm{SiO} 2 \mathrm{nH} 2 \mathrm{O}$ as a gel hardened for a period of time. In the experiment there was the sandy soil with particles $\approx 0,5-1,5 \mathrm{~nm}$, the concentration of silica sol solution having been not less than $30 \%$. In that case the substance which is like sand was used but they were different in size. According to SST soil strengthening is $0,1-0,2 \mathrm{MPa}$, its value being the same as one when applying $\mathrm{Na} 2 \mathrm{SiO} 3$. But silica sol is a pure substance for the environment. Thus, the properties of $\mathrm{SiO} 2$ $\mathrm{nH} 2 \mathrm{O}$ are good for both strengthening process and the environment.

Silica sol blocking action technology (SBT) is quite new one for transport construction and geoprotection. The result of the technology is formation of the special surface screen on polluted concrete. Oil pollutions were considered in the experiment that is why the concrete was saturated with oil products. Then the concrete having about $7-10 \%$ oil products absorbed was put into silica sol solution for saturation within a few hours. Then, in 3 days later, the system was saturated with water. In 1-3 days the aqueous extract was taken from the system for the oil product analyzer test. The oil products were not found in it. The research has shown that the screen formed on the surface of the concrete was 2-4 mm thick. It consisted of silica sol and some substances of interaction between $\mathrm{SiO} 2 \mathrm{nH} 2 \mathrm{O}$ and the stone.

The Table 5 sums up the results of new technologies given above and their application in transport construction.

Table 5. Results of the study of new technologies for transport construction.

\begin{tabular}{|l|l|l|}
\hline \multicolumn{1}{|c|}{ New technologies } & \multicolumn{1}{|c|}{ New technologies' results } & $\begin{array}{l}\text { New technologies' application } \\
\text { in transport construction }\end{array}$ \\
\hline $\begin{array}{l}\text { Silica sol detoxication technology } \\
\text { (SDT) }\end{array}$ & $\begin{array}{l}\text { Reaction between heavy metal ions } \\
\text { and } \mathrm{SiO}_{2} \mathrm{nH}_{2} \mathrm{O}\end{array}$ & $\begin{array}{l}\text { Detoxication of heavy metal ions in } \\
\text { soils }\end{array}$ \\
\hline $\begin{array}{l}\text { Silica sol absorption technology } \\
\text { (SAT) after concrete hardening }\end{array}$ & $\begin{array}{l}\text { Decrease of water absorption and } \\
\text { increase of concrete hardness }\end{array}$ & $\begin{array}{l}\text { Both blocking salt efflorescence } \\
\text { and environmental protection }\end{array}$ \\
\hline $\begin{array}{l}\text { Soil strengthening technology } \\
(\mathrm{SST})\end{array}$ & $\begin{array}{l}\text { Binding properties of silica gel due } \\
\text { to sol } \rightarrow \text { gel conversion }\end{array}$ & $\begin{array}{l}\text { Strengthening a sandy soil, anti- } \\
\text { dusting finely-pulverized particles. } \\
\text { Soil strength is } \approx 0,1-0,2 \text { MPa }\end{array}$ \\
\hline $\begin{array}{l}\text { Silica sol blocking action } \\
\text { technology (SBT) }\end{array}$ & $\begin{array}{l}\text { Formation of the protective surface } \\
\text { screen on concrete polluted by oil } \\
\text { products }\end{array}$ & $\begin{array}{l}\text { Prevention of oil pollution } \\
\text { extraction from a stone into the } \\
\text { environment due to the surface } \\
\text { screen which is } \approx 2-4 \text { mm sick }\end{array}$ \\
\hline
\end{tabular}

According to the Table 5 it is possible to assume that when applying SDT silica sol can have a good strengthening effect because of both SST processes and the presence of Ca (II) [6-13]. If Ca (II) is added in silica sol solution one can obtain calcium silicate that results in soil strengthening. Proceedings [14-21] investigate the mechanism of concrete's main properties increase over calcium silicate hydrates. In these papers some of them are described, namely: decrease of water absorption as well as salt efflorescence [18-21]. As for SBT, it is quite good because of concrete surface screen. This technology is the best for environmental protection as it enables the useful properties of a stone, in particular: concrete can absorb oil products and then block them in the stone by silica sol screen which is $2-4 \mathrm{~mm}$ sick.

Apart from these technologies silica sol can be used for other purposes, e.g. a new method of identification of soil pollutions such as heavy metal ion pollution can be suggested. The method is qualitative one and it is based on the sediments' colour (see the Table 2). The point of the method is the reaction between heavy metal ions, $\mathrm{Me}^{2+}$ or $\mathrm{Me}^{3+}$, in the aqueous extract of a polluted soil and silica sol solution. The result of the reaction is the formation of different 
colours' sediments. For qualitative express method realization one must take 1 volume of a polluted soil and 2 volumes of water and mix them in order to get samples of the aqueous extract. Then these samples must be mixed with $30 \%$ silica sol solution. The Table 6 presents the results of the analysis of the soil polluted by heavy metal ions to $1000 \mathrm{TC}$.

Table 6. Qualitative express method of heavy metal ion pollution identification.

\begin{tabular}{|c|c|c|}
\hline $\begin{array}{c}\text { Heavy metal ions in the soil } \\
\text { (aqueous extract) }\end{array}$ & $\begin{array}{c}\text { Level of pollution, number } \\
\text { of TC }\end{array}$ & $\begin{array}{c}\text { Colour of the sediments } \\
\text { according to silica sol reaction }\end{array}$ \\
\hline $\mathrm{Cu}(\mathrm{II})$ & $1000-2000$ & turquoise \\
\hline $\mathrm{Fe}(\mathrm{II})$ & $1000-2000$ & rust \\
\hline $\mathrm{Ni}(\mathrm{II})$ & 1000 & light green \\
\hline $\mathrm{Pb}(\mathrm{II})$ & $\approx 2000$ & white \\
\hline $\mathrm{Cd}(\mathrm{II})$ & $\approx 2000$ & white \\
\hline
\end{tabular}

It is worth mentioning that one must know that if there is white color of $\mathrm{Pb}$ (II) or $\mathrm{Cd}$ (II) sediments it is important to perform other reactions, e.g. the reaction with $\mathrm{I}^{-}$ions which has yellow sediment for $\mathrm{Pb}$ (II) identification or the reaction with $\mathrm{S}^{2-}$ ions which results in the formation of the lemon-yellow sediment for Cd(II) identification. Thus, it is possible to use qualitative express method of free heave metal ion identification in soils. This method lets everybody easily determine geosphere pollution at once and detoxicate it by means of silica sol.

\section{Conclusions}

1. 4 new technologies based on silica sol properties are examined to find more possibilities for lithosphere preservation during transport construction.

2. The research introduces silica sol detoxication technology (SDT) for heavy metal ion detoxication in soils; silica sol absorption technology (SAT) for concrete surface improvement; soil strengthening technology (SST) for strengthening of a soil to $0,1-0,2$ $\mathrm{MPa}$; silica sol blocking action technology (SBT) for the formation of the screen on the surface of a stone polluted by oil products.

3. The new qualitative express method for free heavy metal ion identification in transport systems' soils by means of silica sol is suggested. The point of the method is colour of the sediments due to the reactions between a soil's aqueous extract and silica sol.

\section{References}

1. L.B. Svatovskaya, A.A. Kabanov, M.M. Sychov, IOP Conference Series: Earth and Environmental Science 90,1755-1315 (2017) DOI: 10.1088/1755-1315/90/1/012010

2. L.B. Svatovskaya, A.A. Kabanov, M.M. Sychov, IOP Conference Series: Earth and Environmental Science 90, 1755-1315 (2017) DOI: 10.1088/1755-1315/90/1/012009

3. L.B. Svatovskaya, A.A. Kabanov, M.M. Sychov, Procedia Engineering 189, 398-403 (2017) DOI:10.1016/j.proeng.2017.05.063

4. L.B. Svatovskaya, O.V. Urov, A.A. Kabanov, Procedia Engineering 189, 454-458 (2017) DOI: 10.1016/j.proeng.2017.05.073

5. L.B. Svatovskaya, M.V. Shershneva, M.M. Baidarashvili, N.I. Yakimova, A.V. Khitrov, Proceedings of the International Conference on Sustainable Waste Management and Recycling: Construction Demolition Waste, 199-203 (2004) 
6. L.B. Svatovskaya, A.S. Sakharova, M.M. Baidarashvilly, A.V. Petriaev, Proceedings of the 14th International Conference of International Association for Computer Methods and Recent Advances in Geomechanics, 152 (2014)

7. A.M. Sychova, L.B. Svatovskaya, S.V. Mjakin, I.V. Vasiljeva, Electron Beam Modification of Solids: Mechanisms, Common Features and Promising Applications, 35-37 (2009)

8. A.M. Sychova, L.B. Svatovskaya, S.V. Mjakin, I.V. Vasiljeva, Electron Beam Modification of Solids: Mechanisms, Common Features and Promising Applications, 39-47 (2009)

9. L.L. Maslennikova, L.B. Svatovskaya, S.V. Mjakin, I.V. Vasiljeva, Electron Beam Modification of Solids: Mechanisms, Common Features and Promising Applications, 57-61 (2009

10. L.B. Svatovskaya, , N.I.Yakimova, O.Y. Trunskaya, E.V. Rusanova, N.B. Krylova, Proceedings of the International Conference on Sustainable Waste Management and Recycling: Construction Demolition Waste (2004)

11. A.M. Sychova, A. Solomahin, V. Kotovich, L.B. Svatovskaya, Y. Kamenev, E3S Web of Conferences 33, 02058 (2018) DOI: https://doi.org/10.1051/e3sconf/20183302058

12. N. Gusev, L.B. Svatovskaya, A. Kucherenko, E3S Web of Conferences 33, 02069 (2018) DOI: https://doi.org/10.1051/e3sconf/20183302069

13. A. Sychova, M. Sychov, E. Rusanova, Procedia Engineering 189, 681-687 (2017) DOI: 10.1016/j.proeng.2017.05.108

14. A. Sychova, A. Solomahin, A. Hitrov, Procedia Engineering 189, 688-694 (2017) DOI: 10.1016/j.proeng.2017.05.109

15. A. Kavetsky, G. Yakubova, M. Sychov, Q. Lin, G. Walter, D. Chan, S. Yousaf, H. Socarras, J. Abrefah, K. Bower, Nuclear Science and Engineering 159, 321-329 (2008)

16. A.G. Kavetsky, S.P. Meleshkov, M.M. Sychov, Polymers, Phosphors and Voltaics for Radioisotope Microbatteries, CRC Press 1, 1-38 (2002)

17. M.M. Sychov, Semiconductors 40(9), 1016-1020 (2006)

18. V.V. Bakhmetyev, S.V. Mjakin, V.G. Korsakov, A.M. Abyzov, M.M. Sychov, Glass Physics and Chemistry 37(5), 549-554 (2011)

19. M.M. Sychov, K.A. Ogurtsov, V.T. Lebedev, Yu.V. Kulvelis, Gy. Török, A.E. Sokolov, V.A. Trunov, V.V. Bakhmetyev, A.A. Kotomin, S.A., Dushenok, A.S. Kozlov, Semiconductors 46(5), 696-700 (2012)

20. M.V. Gravit, V.I. Gumenjuk, M.M. Sychov, O. Nedyshkin, Procedia Engineering 117, $119-125$ (2015)

21. S.V. Mjakin, T.S. Minakova, V.V. Bakhmetyev, M.M. Sychov, Russian Journal of Physical Chemistry 90, 240-245 (2016) 